University of Nebraska - Lincoln

DigitalCommons@University of Nebraska - Lincoln

March 2002

\title{
Pre-/Post-Knowledge Assessment of an Earth Science Course for Elementary/Middle School Education Majors
}

David C. Gosselin

University of Nebraska - Lincoln, dgosselin2@unl.edu

Joy L. Macklem-Hurst

Mission Middle School, 2202 Washington St., Bellevue, NE

Follow this and additional works at: https://digitalcommons.unl.edu/natrespapers

Part of the Natural Resources and Conservation Commons

Gosselin, David C. and Macklem-Hurst, Joy L., "Pre-/Post-Knowledge Assessment of an Earth Science Course for Elementary/Middle School Education Majors" (2002). Papers in Natural Resources. 135.

https://digitalcommons.unl.edu/natrespapers/135

This Article is brought to you for free and open access by the Natural Resources, School of at DigitalCommons@University of Nebraska - Lincoln. It has been accepted for inclusion in Papers in Natural Resources by an authorized administrator of DigitalCommons@University of Nebraska - Lincoln. 


\title{
PRE-/POST-KNOWLEDGE ASSESSMENT OF AN EARTH SCIENCE COURSE FOR ELEMENTARY/MIDDLE SCHOOL EDUCATION MAJORS
}

\author{
David C. Gosselin
}

Nebraska Earth Science Education Network, Institute of Agriculture and Natural Resources, University of Nebraska-Lincolin, Lincoln, NE 68588-0517,dgosselin2@unl.edu

Mission Middle School, 2202 Washington St., Bellevue, NE 68005

\begin{abstract}
Many K-12 educators never experience active learning processes in their science courses that are part of their formal teacher preparation program because of the prevalence of the didactic teaching approach (lecture-read-answer) used in undergraduate science classrooms. From an educational perspective there are substantial benefits to experiencing the process of science through active learning strategies. A 16-week, one semester course entitled, "Earth Systems Science for Educators" has been designed at the University of Nebraska-Lincoln to use an active learning approach to improve student knowledge of basic Earth science concepts. To evaluate the extent to which their knowledge has improved, we developed a fairly simple assessment instrument, which consists of 38 statements in which the student responds true-false-"I do not know." Based on pre- and post-course assessments of 108 elementary and middle-level education majors who took the class in 5 different semesters from 1998 to 2000, there was an average increase in their content knowledge of 30 percent.
\end{abstract}

Keywords: Geoscience education; undergraduate education; testing and evaluation; Geoscience teaching and curriculum

\section{INTRODUCTION}

One of the greatest challenges to implementing reform based on the National Science Education Standards (NRC, 1996) is to increase the extent to which K-12 students experience science as process. Unfortunately, many K-12 educators never experience the process during their formal teacher preparation program (NSF97-171) because of the well documented prevalence of the didactic teaching approach (lecture-read-answer) used in undergraduate science classrooms (Fones et al. 1999; Wagner 1993; Renner and Marek 1988; Stallings et al. 1981). In addition to its prevalence, this approach also contributes to the general tendency for education majors to dislike science, which, in turn, leads to future teachers who generally lack enthusiasm for the subject.

It is well documented that the attitudes future teachers have for science can be improved if they experience science using active learning strategies that include a hands-on, inquiry-oriented approach (Fones et al., 1999; Beiswenger et al., 1998; Martin et al., 1992; Stallings et al., 1981). Using this approach has the additional benefit of providing teachers with first-hand experience with the process of science. Thus increasing the probability that they will use active learning strategies in their classrooms because one is likely to teach as one is taught. Although there are substantial benefits to experiencing the process of science from an educational perspective, it also needs to be demonstrated from a scientific perspective that our future teachers are gaining content knowledge using this approach.

The purpose of this paper is threefold. First, we provide an overview of a 16-week, one semester, Earth Systems Science course offered by the School of Natural Resource Sciences at the University of Nebraska-Lincoln (UNL). Second, we present a pre- and post-test knowledge assessment to document changes in content knowledge and provide results obtained from108 students over five semesters from the spring 1998 to spring 2000. Thirdly, we provide a qualitative assessment of the student's attitudes toward the class and what we have learned over the last three years from our students.

\section{COURSE DESCRIPTION}

Earth Systems Science for Educators is designed to fulfill the science requirements for students enrolled in Teachers College. Enrollment is limited to 24 students. We assume this is the last earth science class the student will take. Earth science has an exceptionally broad scope. Because these are future educators, we focus on fundamental earth science concepts related to eight general content areas, which are consistent with those outlined in both the National and Nebraska K-12 science education standards. We emphasize that the Earth is a system in which "everything is connected to everything else." Using an Earth systems science focus provides a framework to help connect earth science phenomena back to the student's world. This helps make science relevant from both personal and social perspectives. We challenge the students to understand and apply basic earth science concepts to their "real world."

The students meet twice a week for a total of 4.5 hours. The content information is primarily presented through the use of both hands-on and minds-on approaches, including inquiry-based activities. These approaches provide students the opportunity to become actively involved in their learning and to improve their 
science process skills. To further develop or enhance the students conceptual understanding of science as process, they participate in two collaborative projects in which they collect and interpret data. The first project requires the students to collect weather data. During the first week of class, students learn to use basic weather instruments that include: a maximum and minimum thermometer, a barometer, a sling psychrometer, a rain gauge, and an anemometer. Each member of the four person team collects data for seven days at their place of residence and a daily surface weather map from the Weather Channel website. The second project has students obtain daily stream flow data from the U.S. Geological Survey's real-time surface water data website for specific sites along a major Nebraska River. Each team is assigned a location for which they collect data for one week. In both projects, students plot data on graphs, summarize data in tables, explain how instrument location may influence their data, use their knowledge of atmospheric and hydrologic processes to develop explanations for their data, and present their findings to the class.

Knowledge Assessment - Documenting student learning has become increasingly important as academic departments undergo periodic internal and external reviews. One method of documentation is to use a pre-

\begin{tabular}{|l|l|}
\hline Earth Science Topics & $\begin{array}{l}\text { Related Assessment } \\
\text { Questions }\end{array}$ \\
\hline Earth Systems & 14,18 \\
\hline Earth in the Solar System & $1,3,4,5,6,9,11$ \\
\hline $\begin{array}{l}\text { Earth in 3-Dimensions } \\
\text { (maps) }\end{array}$ & 23,35 \\
\hline $\begin{array}{l}\text { Energy and Matter in the } \\
\text { Earth System }\end{array}$ & 10,13 \\
\hline $\begin{array}{l}\text { Earth's Weather and } \\
\text { Climate }\end{array}$ & 8,37 \\
\hline $\begin{array}{l}\text { Earth's Dynamic Water } \\
\text { System }\end{array}$ & $20,21,28,29,33$ \\
\hline $\begin{array}{l}\text { Earth Resources: Rocks and } \\
\text { Minerals }\end{array}$ & $16,17,19,27,36,38$ \\
\hline Dynamic Earth & $7,25,30$ \\
\hline $\begin{array}{l}\text { The Earth in 4-dimensions: } \\
\text { Earth History }\end{array}$ & $2,12,22,25,32,34$ \\
\hline General & $24,26,31$ \\
\hline
\end{tabular}

Table 1. Topics covered in Earth System Sciences for Educators and related knowledge assessment questions. and post-course assessment. In addition, to documenting what the students learn, the assessment can provide the instructor with information about the knowledge, and potential misconceptions, with which the students enter the class. The assessment is also a tool for identifying aspects of the course that can be improved.

Our pre- and post-course assessment instrument consists of 38 statements that focus on content knowledge (Figure 1). We used the content requirements outlined in the National Science Education Standards (NRC, 1996) and the Earth Science Content Guidelines (AGI, 1991), as well as drawing from an evaluation of misconceptions in the earth sciences (Philips, 1991). Our assessment utilizes a true-false-"I do not know" format. The "I do not know" category is incorporated to minimize guessing. Some of the questions can be better written, but to compare data over several years, we have not modified the questionnaire. The relationship between Earth science topics and assessment questions is provided in Table 1.

Figure 2 provides a summary of the pre- and post-assessments given to 108 students from the Spring 1998 to Spring 2000 semesters. Students included sophomores to seniors. The average score for the pre-course assessment was $21 \pm 5.1(1 \sigma)$ and the range was 5 to 31 . (Table 2). The average score of the post-course assessment was $30 \pm 3.4(1 \sigma)$ and the range was 16 to 36 . The average number of correct answers increased by 30 percent between the pre-and post-test. An analysis of variance using a simple F-test indicates the results from the

\begin{tabular}{|l|c|c|c|c|}
\hline \multirow{2}{*}{ Class } & \multicolumn{2}{|c|}{ Pre-Course } & \multicolumn{2}{c|}{ Post Course } \\
\cline { 2 - 5 } & $\begin{array}{c}\text { Average } \\
\text { Score }\end{array}$ & Std. Dev. & $\begin{array}{c}\text { Average } \\
\text { Score }\end{array}$ & Std. Dev \\
\hline $\mathbf{1 9 9 8}$ & 20 & 6.3 & 26 & 3.9 \\
\hline Spring & 23 & 3.8 & 31 & 4.0 \\
\hline Fall & 20 & 5.7 & 31 & 3.6 \\
\hline $\mathbf{1 9 9 9}$ & 21 & 3.5 & 30 & 2.2 \\
\hline Spring & & & \multicolumn{3}{|c|}{} \\
\hline Fall & 22 & 5.6 & 30 & 2.6 \\
\hline 2000 & 21 & 3.1 & 30 & 3.4 \\
\hline Spring & & & \multicolumn{2}{|c|}{} \\
\hline Average & 21 & & \\
\hline
\end{tabular}

Table 2. Summary of the average and standard deviation (Std. Dev.) values for the pre- and post-course knowledge assessment for Earth System Science for Educators class. 
Instructions: Circle $\mathrm{T}$ if the statement is true, $\mathrm{F}$ if the statement is false, and I if you do not know the answer. Please do not guess.

1. T F I Planet earth is only one part of the solar system.

2. T F I Planet earth is 4.6 billion years old.

3. T F I A planet's characteristics are controlled by its size and distance from the sun.

4. T F I Circular features on the moon and other planets were created by volcanoes.

5. T F I Night and day are caused by the sun moving around the earth.

6. T $\mathrm{F}$ I The Moon goes around the earth in a single day.

7. T F I If we do not consider the oceans, the Earth is a solid sphere.

8. T F I Energy from the Sun controls the weather.

9. T F I Impact craters are found on all planets except the earth.

10. T F I Without the ability of energy to change forms, the earth would be a dead planet.

11. T F I The Universe consists of only the Sun and planets in our solar system.

12. T F I The Earth's surface has been the same since the beginning of time.

13. T F I All radioactivity is derived from human activity.

14. T F I A system has characteristic properties, structure and composition.

15. T F I Nebraska was once covered by vast inland seas.

16. T F I The primary source for natural resources are rocks and minerals.

17. T F I Minerals are composed of rocks.

18. T F I Energy and/or matter both need to enter and leave a system for it to function.

19. T F I Minerals have characteristic composition, structure and naturally occur.

20. T F I The water and rock cycles are related.

21. T F I Once water has accumulated in the ocean, it remains there.

22. T F I Dinosaurs and humans lived on the earth at the same time.

23. T F I To best represent an area, all available information should be compiled on one map.

24. T F I All data collected by scientists is accurate and precise.

25. T F I Earth's natural processes may take from fractions of a second to billions of years.

26. T F I Gravity acts the same on all objects no matter what their composition.

27. T F I Soils are deposited as natural rock layers

28. T F I Groundwater typically occurs as underground rivers and lakes.

29. T F I After water percolates into the groundwater system it does not move.

30. T F I The process by which mountains form and earthquakes occur are caused by the same internal process within the earth.

31. T F I We know all we need to know about the earth to make appropriate and informed decisions about environmental issues.

32. T F I Past environmental conditions on Earth can be interpreted from fossils.

33. T F I The physical and chemical characteristics of the groundwater are not affected by the rocks and other geologic materials within which it occurs.

34. T F I The activity of water, wind and ice have all shaped Nebraska's landscape.

35. T F I To determine the distance between points on a map, you need to know the scale of the map.

36. T F I Igneous, metamorphic and sedimentary are the major classes of rocks.

37. T F I The chemical composition of the earth's atmosphere does not change.

38. T F I Sedimentary rocks are derived from previously existing rocks.

Figure 1. Knowledge assessment of earth systems science for educators. 


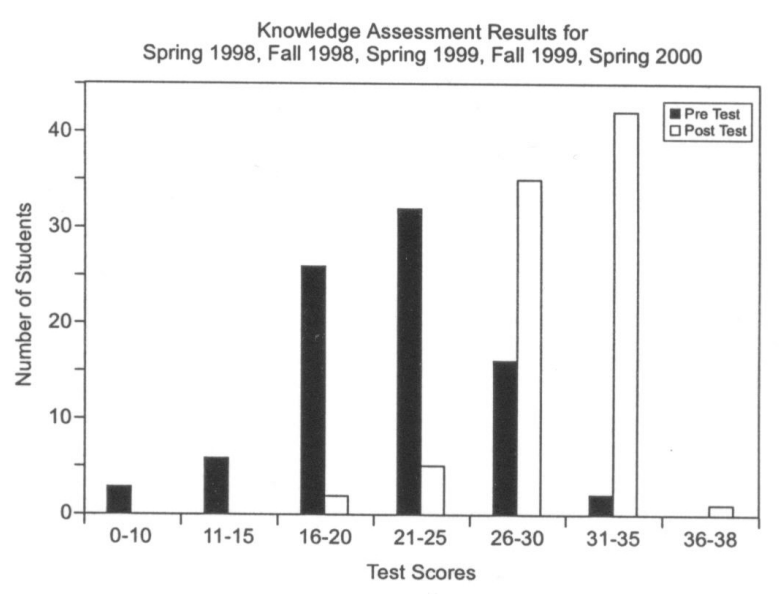

Figure 2. Comparison of pre- and post-course knowledge assessment results. Number of students sampled was 108.

pre- and post-knowledge assessment for the individual semesters and all semesters combined are statistically different $(p=0.05)$. In the spring semester of 1999, 14 of 24 students had pre-course scores less than 20 having an average of 16 . The post-course scores of these 14 students increased by an average of 15 points to 31 . These data indicate that the student knowledge of Earth science concepts improved.

Responses for the individual questions from the preand post assessment as they relate to the specific earth science topics are compared in Figures 3a through e. The average score of the pre-course assessment indicates that students understood 55 percent of the concepts as they entered the class. However, responses to individual questions indicates that students understood some topics better than others. For example, over 90 percent of the students knew that: the scale of a map is used to determine the distance between two points (\#35); the Earth's surface has changed since the beginning of time (\#12); not all data collected by scientists is accurate and precise (\#24); and the activity of water, wind, and ice have shaped Nebraska's landscape (\#34).

In a state that has a significant agricultural economy in which water and soil are important, it was interesting to note that only 13 percent of the students knew that ground water does not typically occur as underground rivers and lakes (\#28) and that only 15 percent understood that soils were not deposited as rock layers (\#27). Although students generally recognized that $\mathrm{Ne}$ braska's landscape has changed over time, only 35 percent knew that it once was covered by inland seas (\#15). The topic about which students were least knowledgeable was rocks and minerals. Specifically, they had trouble distinguishing between rocks and minerals (\#17) and did not know that sedimentary rocks are derived from

Figure 3a - e. Comparison of pre- and post-course knowledge assessment by Earth science topics. See Table 1.
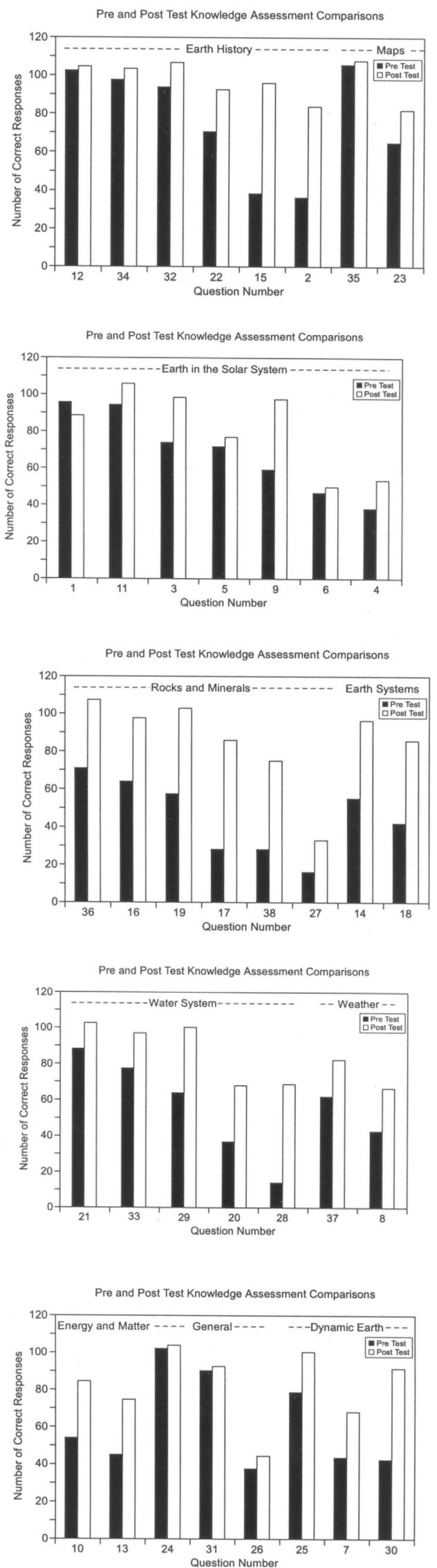


\begin{tabular}{|c|c|c|}
\hline Subscale & $\begin{array}{c}\text { Average Score } \\
\text { (Out of 4.00) }\end{array}$ & $\begin{array}{c}\text { Number of } \\
\text { Questions }\end{array}$ \\
\hline $\begin{array}{c}\text { General Student } \\
\text { Attitude }\end{array}$ & 3.50 & 4 \\
\hline $\begin{array}{c}\text { Teaching } \\
\text { Methods }\end{array}$ & 3.37 & 4 \\
\hline Course Content & 3.17 & 4 \\
\hline $\begin{array}{c}\text { Student Interest } \\
\text { in Class }\end{array}$ & 3.83 & 4 \\
\hline Instructor & 3.59 & 5 \\
\hline Total & 3.29 & 21 \\
\hline
\end{tabular}

Table 3. Summary of course/instructor evaluations during 1998-1999 and fall 1999 classes.

existing rocks. Only 65 percent of the students recognized that the major rock types are igneous, metamorphic, and sedimentary. In the context of understanding the importance of rocks and minerals, only 59 percent recognized their importance as natural resources.

Results from the post-course assessment indicated the average score improved from 55 to nearly 80 percent. There was at least a 25 percent improvement in the score for 42 percent of the questions. On the pre-test 24 percent of the questions were correctly answered 80 percent of the time. Whereas on the post-test, 63 percent of the questions were answered correctly 80 percent of the time. There was improvement on each question with the exception of number 1, the recognition that the Earth is only one part of the solar system. By the end of the course, the following are examples of improvement on individual questions: 56 more students (52 percent) recognized that ground water did not typically occur as underground rivers and lakes (\#28); 44 percent more students recognized that sedimentary rocks are derived from previously existing rocks (\#38); nearly 80 percent of the students learned that inland seas once covered $\mathrm{Ne}$ braska (\#15); and there was a 55 percent increase in the number of students who learned rocks are composed of minerals (\#17).

Qualitative Attitude Assessment - Individual discussions with students and responses to formative assessment questions during each semester suggest that although students were not very enthusiastic about science coming into the class, their attitude toward science was more favorable upon completion of the class. For example, several students stated that prior to this class they would not have placed much emphasis on teaching science. However, by the end of the class, they had a better understanding of the nature of science and would incorporate it into their future classroom activities. Some representative student comments include:

“As far as content - wow! I've really learned a lot this semester. The material is new to me and I feel confident I could teach it to students in the future"

"The information that we are going over is presented in a way that I can usually relate to and understand."

"I didn't expect to do so many experiments and projects, which I find very interesting. I have learned a lot of new information and am planning on using it in my classroom."

"I do think these activities are good, it helps us see things through the eyes of the younger students and will aid us when we end up planning our own science classes."

"I learned a lot not only about geology, but education and instruction as well - very worthwhile."

Course/Instructor Evaluations - Using the standardized UNL course evaluation instruments, students were asked to evaluate the course at the end of each of the five semesters. The evaluation instrument consisted of 21 items that employed a four item Lickert scale consisting of agree strongly (4 points), agree moderately (3 points), disagree moderately (2 points) and disagree strongly. Because the evaluation form changed after the first two semesters, the most recent data from 69 students who participated in the class during the 1998-1999 academic year and Fall 1999 are summarized in Table 3.

Overall, the students gave this course a high approval rating as indicated by an average score of 3.5 for the assessment items, "Overall, the course was good" and "I think the course was taught well." The students generally thought it was a worthwhile course (3.5) and that they would take another course taught this way (3.64). Although the majority strongly agreed that they would want to take another course taught this way, these same students also moderately agreed (2.96) that they learned more when other teaching methods are used. This contrast is somewhat surprising if we consider that research indicates that the majority of people learn better when they are physically and mentally engaged in activities that are designed to develop process skills than they do in a classroom environment in which "teaching by telling" is the dominant teaching style (Bransford et al, 1999). Our sample population consists of students who, for the most part, have not only done well in the latter classroom environment, but enjoyed it 
enough to want to become an educator. We suggest that the results are not surprising because although the students enjoy the class, their exposure to this potentially new classroom environment has been relatively limited and not enough to convince them that they may actually learn better in it.

\section{INSTRUCTOR'S SELF ASSESSMENT}

Based on six semesters of interaction with students having a wide range of backgrounds, we have learned that elementary and middle-level education majors:

-can improve their content knowledge.

- can develop the skills to participate in a scientific investigation if given the opportunity and an environment where the use of these skills is allowed to develop

- are capable of collecting data and evaluating its quality.

- can develop their own research questions. Yet, this is difficult and frustrating for most of them because they have had limited experience in the art of developing addressable questions.

- struggle to use data and information to address research questions. Most of them have never had to develop a solution to a question for which there was not a pre-existing or expected answer.

In our role as instructors, but more importantly, as scientists, we have learned:

- to use a variety of approaches to engage the student. There are many different learning styles

- instructors must take some responsibility for the extent to which students learn. Sometimes it is clearly the students lack of effort. In other cases, instructors may need to use alternative strategies to communicate the concept.

- instructions and procedures need to be explicit.

- to be flexible and open to students suggestions for improving the class.

- students cannot know how to do something if they have no prior experience. We should not assume students know how to do something. We must ask first.
- students need an opportunity to be engaged in the processes of scientific inquiry if their perception of science is to change.

\section{CONCLUSIONS}

Based on the interaction with 108 students over five semesters, the educational approach used in this class provided pre-service elementary and middle-level education majors to improve their content knowledge on average by 30 percent. Although this assessment was designed specifically for the topics covered in this class and for Nebraska, it provides a model that others may follow. It typically takes students less than ten minutes to complete and less than a half hour to score twenty-four tests. Because of accreditation requirements, academic departments in higher education institutions are increasingly being asked to formalize their assessment process for student learning. This is a fairly simple instrument, but it does document that students are learning basic Earth science content.

Although this instrument documents an apparent improvement in content knowledge, there are a variety of questions that remain. For example, to what extent do the students need to experience this type of classroom environment for them to employ these approaches in their own classroom? We also need to investigate the extent to which this type of class fosters learning with understanding and the ability of the student to apply their knowledge to new situations. We also need to compare short- and long-term student learning and retention in this class to other Earth Science classes, which are taught with more traditional approaches.

\section{REFERENCES}

American Geologic Institute (AGI), 1991, Earth Science Content Guidelines: Alexandria, VA., 76 p.

Beiswenger, R.E., Stepans, J. I., and McClurg, P. A., 1998, Developing science courses for prospective elementary teachers: An experimental program at the University of Wyoming succeeds in preparing better science teachers: Journal of College Science Teaching. v. 27, p. 253-257.

Bransford, J.D., Brown, A.L., and Cocking, R.R., 1999, How People Learn: Brain, Mind, Experience, and School: Washington, D.C., National Academy Press, $319 \mathrm{p}$.

Fones, S., Wagner, J., and Cladwell, E., 1999, Promoting attitude adjustments in science for pre-service elementary teachers: Journal of College Science Teaching, v. 28, p.231-236.

Gosselin, D.G. and Hurst, J.L., 2000, Earth systems science for elementary/middle school education majors: GeoSciEd III, Third International Conference on Geoscience Education, University of New South Wales, Conference Proceedings, January 16-21, 2000, p. 164-167. 
Martin, L. E., Ryan, J. M.., and Carpenter, J. R.,1992, Improving teacher attitudes toward science and increasing their knowledge of Earth science: Journal of Geological Education, v. 40, p. 216-221.

National Research Council (NRC), 1996, National Science Education Standards. National Academy Press, Washington, D.C., 262p.

National Science Foundation (NSF) 97-171, 1997, Geoscience Education: A Recommended Strategy. A report based on an August 29-30, 1996, Workshop form the Geoscience Education Working Group to the Advisory Committee for Geosciences and the Directorate for Geosciences of the National Science Foundation.

Philips, W.C., 1991, Earth science misconceptions: The Science Teacher. February Issue, 21-23.

Renner, J. W., and Marek, E. A., 1988, The Learning Cycle and Elementary School Science Teaching, Portsmouth, NH, Heinemann Publishing.

Stallings, E. S., Carpenter, J. R., Astwood, P. M., and Fitzpatrick, H. B., 1981, Effects of two contrasting teaching strategies in an investigative Earth science course for elementary education majors: Journal of Geological Education, v. 29, p.76-82.
Wagner, J. R., Barbary, S. W., and Astwood, P.M., 1995, Full-circle partnerships for elementary school science education-A collaborative approach to group learning in earth science: Journal of Geological Education, v. 43, p.376-380.

\section{About the Authors}

David Charles Gosselin is director of the Nebraska Earth Science Education Network and associate professor with the School of Natural Resource Sciences and Conservation and Survey Division at the University of $\mathrm{Ne}$ braska-Lincoln. He received his B.A. in Geology from the University of St. Thomas, St. Paul, MN in 1982 and a Ph.D in Geology from the South Dakota School of Mines and Technology in 1987.

Joy Macklem-Hurst graduated from the University of Nebraska Lincoln in December 2000 with a Bachelor's of Science in Middle Level Education specializing in math and science. While at UNL, she served as a teaching assistant as well as the logisitical coordinator for the Nebraska Earth Science Education Network. She currently teaches seventh grade math at Mission Middle School in Bellevue, Nebraska.

The greatest obstacle to new learning often is not the student's lack of prior knowledge, but, rather, the existence of prior knowledge. Most college teachers know from experience that it's much harder for students to unlearn incorrect or incomplete knowledge than to master new knowledge in an unfamiliar field.

Classroom Assessment Techniques

Thomas A. Angelo and K. Particia Cross 